\title{
Estimation of genetic parameters for some performance traits in a selected Barred Rock line
}

\author{
Serdar KAMANLI ${ }^{\bowtie}$ \\ Poultry Research Institute, Ankara, Turkey. \\ ORCID: 0000-0003-1936-7550. \\ ${ }^{\square}$ Corresponding author: serdarkamanli@ hotmail.com \\ Received date: 11.05.2019- Accepted date: 05.08.2019
}

\begin{abstract}
This study was conducted to determine the genetic correlation and heritability for age at sexual maturity, body weight at sexual maturity, egg yield, egg weight, egg shape index and $\mathrm{L}^{*}, \mathrm{a}^{*}, \mathrm{~b}^{*}$ values of egg shell in a Barred Rock line was applied selection. For this aim, a total of 1622 pedigreed Barred Rocks were selected. The present estimated heritability values for investigated traits were found between moderate-to-high. However, the heritability of egg yield, eggshell color and body weight at sexual maturity were found lower than those of other traits. It was calculated positive correlations among monthly egg yields, especially between egg yield at the second month with total egg yield. As a conclusion, selection studies did not cause much decrease in genetic variation of studied traits, except for egg yield and body weight at sexual maturity. Monthly egg yield data can be used selection studies.
\end{abstract}

Keywords: Genetic correlation, heritability, layer breeder, performance traits.

\section{Seleksiyon uygulanan Barred Rock hattında bazı performans özellikleri için genetik parametrelerin tahmini}

Özet: Bu çalışma, seleksiyon uygulanan Barred Rock hattında yumurta verimi, cinsel olgunluk yaşı, cinsel olgunluk ağırlığı, yumurta verimi, yumurta ağırlığı, yumurta şekil indeksi ve yumurta kabuk L*, a*, b* değerlerinde kalıtım derecesi ve genetik korelasyonları belirlemek için yürütülmüştür. Bu amaçla, toplam 1622 pedigrili Barred Rock seçilmiştir. İncelenen özelliklerin hesaplanan kalıtım dereceleri orta ile yüksek değerler arasında olduğu görülmüştür. Bununla birlikte, yumurta verimi, yumurta kabuk rengi ve cinsel olgunluk ağırlı̆ğ özelliklerinin kalıtım dereceleri diğerlerine göre daha düşük bulunmuştur. Özellikle ikinci aydaki yumurta verimi ile toplam yumurta verimi arasında olmak üzere, aylık yumurta verimleri arasında pozitif korelasyonlar hesaplanmıştır. Sonuç olarak seleksiyon çalışmaları, incelenen özelliklerden cinsel olgunluk ağırlığı ve yumurta verimi dışındaki özelliklerin genetik varyasyonunda fazla bir azalmaya neden olmamıştır. Aylık yumurta verimi seleksiyon çalışmalarında kullanılabilir.

Anahtar sözcükler: Genetik korelasyon, kalıtım derecesi, performans özellikleri, yumurtacı damızlık.

\section{Introduction}

Poultry meat and egg have been the most important contributors to animal protein requirement of increasing world population. Turkey has been one of the important leading countries in the poultry production and relevant technologies (18). North American and European breeding companies have dominated for hybrid animal materials more than $2 / 3$ of global market $(11,32,33)$. The Poultry Research Institute in Turkey has been continuing its mission of poultry breeding based on layers for many years. In 1995, the selection studies were conducted on 10 pure lines taken from abroad by taking into consideration egg weight, egg yield, age and weight at sexual maturity. In these studies, one white and two brown native hybrids were developed. The performance of hybrids and comparison studies with foreign hybrids have been continued while selection studies have been conducted on pure lines to be used to produce hybrid combinations.

Aims of the poultry breeding programs are to improve the genetic potential of birds through crossbreeding and selection schedules. Poultry breeding studies include, mainly, two stages. The first one covers selection studies to improve performance at pure line level. All genetic parameter estimations, breeding value estimations and molecular genetic methods are performed at this stage. This provides the highest homozigotization in terms of additive gene effects with all the processes (19, 25). Almost all current studies have been related to this stage. The breeding companies have worked on selection studies to improve their layer lines for some performance 
traits such as age at sexual maturity, body weight at sexual maturity, feed conversion ratio, livability, egg yield, egg weight, shell strength, shell color, blood and meat spots and albumen height (33). The second stage of poultry breeding covers hybridization processes of lines developed by selection and comparison of hybrid combinations. At this stage, the special combination capabilities of hybrid lines with general combination capabilities are determined, and thus, non-additive (dominance and epistatic) gene effects are utilized. Highly selected elite sire and dam pure lines construct the basis of today's layer breeding programs. Commercial layers are obtained from three-way or four-way crosses of specific closed pure breeding lines. Barred Rock is one of the lines developed in the Poultry Research Institute. In this breed, egg yield parameters were studied. The aim of this study was to estimate heritability and genetic correlations for some performance traits (age at sexual maturity, body weight at sexual maturity, egg yield, egg weight, egg shape index and $\mathrm{L}^{*}, \mathrm{a}^{*}, \mathrm{~b}^{*}$ values of egg shell) in a Barred Rock line was applied selection.

\section{Material and Methods}

Animals: The Barred Rock line used in this study was selected for generations using multi-trait selection methodology considering four traits (egg yield, egg weight, age and body weight at sexual maturity) from 1996 up to now. With regards to the selection criteria, superior birds ( 450 hens and 50 cocks) were selected from the base populations; 50 families were formed ( 9 hens were artificially inseminated with the semen from 1 male). Eggs were obtained from these full-pedigree families and they were incubated. Chicks were hatched and vaccinated against diseases according to the institute vaccination program. Chicks were reared until 16 weeks of age under standard management conditions. When the pullets reached to 16 weeks of age, they were randomly distributed into individual cages with conventional cages. All birds had ad libitum access to water and feed. During rearing and growing periods, the birds were fed commercial starter and grower diets for breeder flock. Layers were fed according to the feeding strategy of the Turkish selection and crossbreeding experiment $(10,18)$. Pullets were kept under a constant artificial lighting for 18 h/day. Records of 1622 pedigreed Barred Rocks were taken. The data were collected between 20 to 43 weeks of age. Monthly egg records were generated by summing each 4 continuous weekly eggs records from 20 to 24,25 to 29,30 to 34 , and 35 to 39 weeks of age. The mean sexual maturity age was measured as the number of days until the first egg was laid. The hen was weighed on the day it laid its first egg and this weight was recorded as sexual maturity weight. Average egg weight of each hen's eggs was recorded by weighing three sequential eggs at every 4 weeks starting from the $24^{\text {th }}$ week to end of the experiment. Egg shape and $\mathrm{L}^{*}, \mathrm{a}^{*}$ and $\mathrm{b}^{*}$ values of egg shell were determined at the same time. In this study, $\mathrm{L}^{*}$, $a^{*}$ and $b^{*}$ values were measured (19) with Minolta Chroma Meter CR 400 (Minolta Co., Osaka, Japan).

Statistical analyses: The descriptive statistics, normality (Kolmogorov-Smirnov) and homogeneity (Levene) tests of the traits were performed by using UNIVARIATE procedure of SAS 9.3 software (Statistical Analysis Systems Institute Inc., Cary, NC). The nonparametric rank transformation was applied in $\mathrm{R}$ package for color parameters and shape index which parametric Box-Cox transformation did not Gaussian distributed traits $(6,19)$.

The restricted maximum likelihood (REML) estimator was used to estimate the variance-covariance components for following multi-trait model;

$$
\mathbf{y}=\mathbf{X} \boldsymbol{\beta}+\mathbf{Z u}+\mathbf{e}
$$

Where $\mathbf{y}$, vector of observations for the trait; $\boldsymbol{\beta}$, vector of fixed effects for the trait; $\mathbf{u}$, vector of random animal effects for the trait; $\mathbf{e}$, vector of random residual effects for the trait; and $\mathbf{X}$ and $\mathbf{Z}$ are incidence matrices relating records of the trait to fixed and random animal effects, respectively $(20,30)$. The sire, dam and residual variance components and additive genetic and environmental covariance matrices for multivariate analysis were estimated from the mixed-model equations by SAS PROC MIXED. Heritability $\left(\boldsymbol{h}_{\boldsymbol{i}}^{\mathbf{2}}\right)$ and genetic correlations $\left(\boldsymbol{r}_{g\left(i i^{\prime}\right)}\right)$, were calculated from the variance and covariance parameters as follows:

$$
\boldsymbol{h}_{i}^{2}=\frac{\sigma_{i a}^{2}}{\sigma_{i a}^{2}+\sigma_{i e}^{2}} \quad r_{g\left(i i^{\prime}\right)}=\frac{\sigma_{i i^{\prime} a}}{\sigma_{i a}^{2}+\sigma_{i^{\prime} a}^{2}}
$$

Where $i$ and $\boldsymbol{i}^{\prime}$ represents the trait(s) of interest and $\boldsymbol{\sigma}_{i \boldsymbol{a}}^{\mathbf{2}}$ and $\boldsymbol{\sigma}_{\boldsymbol{i} \boldsymbol{e}}^{\mathbf{2}}$ are the diagonal elements of $\mathbf{G}_{\mathbf{0}}$ and $\mathbf{R}_{\mathbf{0}}$ matrices, respectively. Also, $\sigma_{i i{ }^{\prime} a}$ stands for the additive genetic covariance between the traits $I$ and $i^{\prime}$. The estimations of genetic correlation and heritability and their standard errors for subjected traits were obtained by SAS interactive matrix language (IML) procedure.

\section{Results}

The mean values of the age and body weight at sexual maturity, egg weight, egg shape index, and $\mathrm{L}^{*}, \mathrm{a}^{*}$, $b^{*}$ values of eggshell are shown in Table 1 . The means of age and body weight at sexual maturity, egg weight, shape index, $\mathrm{L}^{*}, \mathrm{a}^{*}$ and $\mathrm{b}^{*}$ values of eggshell, monthly egg yield from 20 to 24,25 to 29,30 to 34 , and 35 to 39 weeks of age and total egg yield from 20 to 43 weeks of age were found as 136.14, 1538.87, 51.31, 76.44, 63.58, 7.95, 
$20.51,14.25,26.88,28.22,28.39$ and 143.93, respectively. The heritability estimations of age and body weight at sexual maturity, egg weight, $L^{*}, a^{*}$ and $b^{*}$ values of eggshell, egg shape index and total egg yield from 20 to 43 weeks of age were determined as $0.41,0.20,0.48,0.20$,
$0.21,0.22,0.33$ and 0.23 , respectively (Table 2). The heritability estimations of monthly records from 20 to 24 , 25 to 29,30 to 34 , and 35 to 39 weeks of age, and the total egg yield were found as $0.33,0.24,0.04,0.01$ and 0.23 , respectively (Table 3).

Table 1. The descriptive statistics of some performance traits

\begin{tabular}{|c|c|c|c|c|c|c|c|}
\hline Variable & $\mathbf{N}$ & Mean & Min. & Max. & $\mathrm{CV}$ & SD & SEM \\
\hline ASM & 1176 & 136.14 & 119 & 164 & 3.97 & 5.4 & 0.16 \\
\hline BWSM & 1176 & 1538.87 & 960 & 2080 & 8.41 & 129.44 & 3.77 \\
\hline EW & 1176 & 51.31 & 42 & 63 & 5.33 & 2.73 & 0.08 \\
\hline $\mathrm{L}^{*}$ & 1078 & 63.58 & 51.1 & 76.7 & 9.22 & 5.86 & 0.18 \\
\hline$a^{*}$ & 1078 & 7.95 & 1.2 & 17.8 & 74.97 & 5.96 & 0.18 \\
\hline$b^{*}$ & 1078 & 20.51 & 4.0 & 45.1 & 14.67 & 3.01 & 0.09 \\
\hline SI & 1077 & 76.44 & 71.93 & 80.39 & 2.65 & 2.02 & 0.06 \\
\hline $\mathrm{EP}_{1}$ & 1176 & 14.25 & 0 & 31 & 35.88 & 5.11 & 0.15 \\
\hline $\mathrm{EP}_{2}$ & 1176 & 26.88 & 0 & 32 & 18.36 & 4.94 & 0.14 \\
\hline $\mathrm{EP}_{3}$ & 1176 & 28.22 & 10 & 32 & 8.57 & 2.42 & 0.07 \\
\hline $\mathrm{EP}_{4}$ & 1176 & 28.39 & 2.0 & 32 & 9.58 & 2.72 & 0.08 \\
\hline $\mathrm{EP}_{\mathrm{T}}$ & 1176 & 143.93 & 61 & 173 & 8.66 & 12.46 & 0.36 \\
\hline
\end{tabular}

ASM: age at sexual maturity, BWSM: body weight at sexual maturity, EW: egg weight, L*: lightness, a*:redness, $b^{*}$ :yellowness, SI: egg shape index, $\mathrm{EP}_{1:} 20$ to 24 weeks of age, $\mathrm{EP}_{2:} 25$ to 29 weeks of age, $\mathrm{EP}_{3}: 30$ to 34 weeks of age, $\mathrm{EP}_{4}: 35$ to 39 weeks of age, $\mathrm{EP}_{\mathrm{T}}$ : from 20 to 43 weeks of age.

Table 2. The estimates of heritability (on diagonal) and genetic correlation (below diagonal) for some performance traits and phenotypic correlations (above diagonal) between traits

\begin{tabular}{lllllllll}
\hline & ASM & BWSM & EW & $\mathbf{L}^{*}$ & $\mathbf{a}^{*}$ & $\mathbf{b}^{*}$ & SI & EPT \\
\hline \multirow{2}{*}{ ASM } & $\mathbf{0 . 4 1}$ & 0.00 & 0.05 & -0.07 & 0.13 & 0.04 & 0.07 & -0.44 \\
& $(0.01)$ & $(0.04)$ & $(0.03)$ & $(0.02)$ & $(0.02)$ & $(0.02)$ & $(0.02)$ & $(0.02)$ \\
BWSM & 0.04 & $\mathbf{0 . 2 0}$ & 0.51 & -0.01 & 0.01 & 0.04 & -0.01 & 0.06 \\
& $(0.04)$ & $(0.02)$ & $(0.02)$ & $(0.02)$ & $(0.02)$ & $(0.02)$ & $(0.02)$ & $(0.02)$ \\
EW & 0.23 & 0.58 & $\mathbf{0 . 4 8}$ & -0.10 & 0.12 & 0.10 & -0.04 & -0.51 \\
& $(0.03)$ & $(0.02)$ & $(0.02)$ & $(0.02)$ & $(0.02)$ & $(0.02)$ & $(0.02)$ & $(0.02)$ \\
L* & -0.50 & -0.02 & -0.14 & $\mathbf{0 . 2 0}$ & -0.68 & -0.30 & 0.04 & 0.00 \\
& $(0.01)$ & $(0.04)$ & $(0.04)$ & $(0.03)$ & $(0.02)$ & $(0.02)$ & $(0.02)$ & $(0.02)$ \\
$\mathrm{a}^{*}$ & 0.82 & -0.14 & 0.62 & -0.33 & $\mathbf{0 . 2 1}$ & 0.43 & -0.09 & -0.07 \\
& $(0.01)$ & $(0.04)$ & $(0.01)$ & $(0.02)$ & $(0.02)$ & $(0.02)$ & $(0.02)$ & $(0.02)$ \\
$\mathrm{b}^{*}$ & -0.19 & -0.01 & 0.27 & -0.68 & 0.44 & $\mathbf{0 . 2 2}$ & -0.10 & 0.06 \\
& $(0.04)$ & $(0.05)$ & $(0.02)$ & $(0.01)$ & $(0.01)$ & $(0.02)$ & $(0.02)$ & $(0.02)$ \\
SI & 0.63 & -0.79 & 0.16 & -0.23 & -0.02 & -0.13 & $\mathbf{0 . 3 3}$ & -0.09 \\
& $(0.01)$ & $(0.01)$ & $(0.03)$ & $(0.03)$ & $(0.04)$ & $(0.02)$ & $(0.01)$ & $(0.02)$ \\
EPT & -0.82 & 0.03 & -0.68 & -0.16 & -0.21 & 0.06 & -0.66 & $\mathbf{0 . 2 3}$ \\
& $(0.01)$ & $(0.05)$ & $(0.01)$ & $(0.03)$ & $(0.04)$ & $(0.05)$ & $(0.01)$ & $(0.01)$ \\
\hline
\end{tabular}

ASM: age at sexual maturity, BWSM: body weight at sexual maturity, EW: egg weight, L*: lightness, a*:redness, b*:yellowness, SI: egg shape index, $\mathrm{EP}_{\mathrm{T}}$ : from 20 to 43 weeks of age. 
Table 3. The estimates of heritability (on diagonal) and genetic correlation (below diagonal) for some egg yield traits and phenotypic correlations (above diagonal) between traits

\begin{tabular}{llllll}
\hline & $\mathbf{E P}_{\mathbf{1}}$ & $\mathbf{E P}_{\mathbf{2}}$ & $\mathbf{E P}_{\mathbf{3}}$ & $\mathbf{E P}_{\mathbf{4}}$ & $\mathbf{E P}_{\mathbf{T}}$ \\
\hline $\mathrm{EP}_{1}$ & $\mathbf{0 . 3 3}$ & 0.27 & 0.08 & 0.03 & 0.66 \\
& $(0.02)$ & $(0.02)$ & $(0.02)$ & $(0.02)$ & $(0.02)$ \\
$\mathrm{EP}_{2}$ & 0.81 & $\mathbf{0 . 2 4}$ & 0.34 & 0.15 & 0.75 \\
& $(0.01)$ & $(0.02)$ & $(0.02)$ & $(0.02)$ & $(0.02)$ \\
$\mathrm{EP}_{3}$ & 0.40 & 0.84 & $\mathbf{0 . 0 4}$ & 0.27 & 0.53 \\
& $(0.02)$ & $(0.02)$ & $(0.03)$ & $(0.02)$ & $(0.02)$ \\
$\mathrm{EP}_{4}$ & 0.52 & 0.73 & 0.86 & $\mathbf{0 . 0 1}$ & 0.47 \\
& $(0.01)$ & $(0.01)$ & $(0.01)$ & $(0.03)$ & $(0.02)$ \\
$\mathrm{EP}_{\mathrm{T}}$ & 0.79 & 0.87 & 0.79 & 0.63 & $\mathbf{0 . 2 3}$ \\
& $(0.01)$ & $(0.01)$ & $(0.01)$ & $(0.01)$ & $(0.02)$ \\
\hline
\end{tabular}

$\mathrm{EP}_{1:} 20$ to 24 weeks of age, $\mathrm{EP}_{2:} 25$ to 29 weeks of age, $\mathrm{EP}_{3}: 30$ to 34 weeks of age, $\mathrm{EP}_{4}: 35$ to 39 weeks of age, $\mathrm{EP}_{\mathrm{T}}$ : from 20 to 43 weeks of age.

\section{Discussion and Conclusion}

The principal traits in layer stocks are weight and age at sexual maturity of hen, egg weight and egg yield. In order to achieve early maturity and egg yield, it is crucial to have correct body weight and uniformity in growing period. The mean of sexual maturity age in this study was found as 136.14 days. This value was lower than those reported by Kumar et al. (14) and Sing et al. (31). The earlier sexual maturity in the current study was the results of selections for sexual maturity and egg yield. The average sexual maturity age of the flock was 162.31 days in 1996 (18) and it has reached 136.14 days at the present. A $3.97 \%$ coefficient of variation for sexual maturity age shows a close uniformity within flock. Selection studies from 1996 to 2019, the sexual maturity weight was reduced from $1996 \mathrm{~g}$ to $1538 \mathrm{~g}$. However, this weight was higher than that of commercial market counterparts, which were 1350-1400 $\mathrm{g}$ (4). Sexual maturity weight is a very important parameter associated with egg weight. The average egg weight in this study was $51.31 \mathrm{~g}$, which was lower than the reported values 55.46 to $62.74 \mathrm{~g}$ in Lohmann and Hyline commercial breeders, respectively $(3,5)$. And also this values was found lower than results of Peebles et al. (23) and Rayan et al. (26). The heavier eggs in laying hens not only decreases the total egg yield but also causes excessive feed consumption. So, the present mean egg weight would not be an obstacle for either higher egg yield or feed efficiency.

Production of uniform dark-brown colored egg shells through laying period is the goal of brown layer breeders (28). In this study, the mean values of $L^{*}, a^{*}$ and $b^{*}$ were found as 63.58, 7.95, 20.51, respectively. It is an important component for measuring shell color (27). The eggshell color of a commercial flock is influenced by many genetic factors, where it is important to ensure uniformity. The coefficients of variation of $\mathrm{L}^{*}, \mathrm{a}^{*}$ and $\mathrm{b}^{*}$ traits were quite high as $9.22 \%, 74.97 \%$ and $14.67 \%$, respectively. Eggs can be classified with respect to shape index, namely as the sharp egg $(<72)$, the standard egg $(72-76)$ or the round egg (>76) (31). The shape index value was found in this study in the upper limit of standard type. The average egg yield from 20 to 24,25 to 29,30 to 34 , and 35 to 39 weeks of age and total egg yield from 20 to 43 weeks of age were found as 14.25, 26.88, 28.22, 28.39 and 143.93, respectively. These findings are similar with reported by other researchers $(36,38,37)$.

It is known that age at sexual maturity was a moderately heritable trait, and there were various heritability estimations between 0.28 to 0.36 in the literature $(1,21,35)$. High heritability estimation (0.41) of the age at sexual maturity in this study was in agreement with that of Lillpers and Wilhelmson (16). The heritability estimation (0.20) for body weight at sexual maturity was lower than those reported in the previous studies $(1,21$, $22,35)$. The low heritability value for body weight at sexual maturity might be indicated that there was little scope for improving this trait through selection. Although the main effort in layer breeding strategy is focused on egg yield, egg weight is, also, a factor in selection schemes. The objective of commercial layer breeding strategies is to obtain lines characterized by moderate egg weight (34). Franches et al. (9) reported that the heritability values for egg weight ranged between 0.20 and 0.33 in different breeds. However, Zhang et al. (39) reported a high heritability value of 0.63 for egg weight. In the current study, the heritability estimation of egg weight trait is similar with those found in the literature $(7,13,17)$.

Estimated heritability ( 0.20 to 0.22$)$ for eggshell color traits in the current study were lower than those $(0.27$ to 0.53 ) reported by Franches et al. (9) and Zhang et al. 
(39) in the different breeds. Johansson et al. (12) and Besbes and Gibson (8) estimated heritability as moderate to high values $(0.23$ to 0.41$)$ for egg shape index. A moderate heritability estimation $(0.33)$ for shape index was consistent with the estimates reported by Johansson et al. (12) and Besbes and Gibson (8).

The heritability estimates of egg yield in the first, second, third, and fourth months of laying hens were determined as $0.65,0.36,0.36$, and 0.38 , respectively. A high heritability (0.43) was estimated for total egg yield. In the literature, the heritability for egg yield in layer breeder were estimated moderate to high (0.21 to 0.48$)$ in previous studies $(2,7,24,29)$. Present findings support these estimations.

There was a quite high genetic correlation (0.58) between body weight at sexual maturity and egg weight (Table 2). Egg weight is strongly correlated with layer age and, consequently, with body weight. Similarly, genetic correlations between age at sexual maturity with brightness and yellowness egg shell were calculated as 0.50 and 0.82 , respectively. In spite of different estimations of genetic correlations between egg yield and other performance traits in the literature, it is well known that egg yield is, negatively, correlated with body weight. The negative relation between sexual maturity age with egg yield implies that the improvement in egg yield will be maintained by earlier sexual maturity. In the present study, the monthly egg yields had a positive correlation among them, indicating that short term of egg production can be used selection studies. Genetic correlations among all traits were fairly high, ranging from 0.40 (between first and third month) to 0.86 (between third and fourth month). Kumari et al. (15) estimated similar genetic correlations for cumulative egg yield up to 12, 16, and 20 weeks of age in two quail lines. In the present study, the genetic correlation between second month and total egg yield was fairly high (0.87), in particular when compared to correlation coefficient $(0.79)$ between both first month and total egg yield, third month and total egg yield.

In conclusion, it was seen a low level of genetic correlation between the traits in this study. The heritabilities of sexual maturity age and egg weight were high, which indicates that it is possible to improve Barred Rock pure line rapidly with respect to egg yield and egg weight. There was a wide variation in the Barred Rock line in terms of egg shape index. In the study, the estimated heritability for shape index showed that the uniform line can be obtained by selection of this trait.

\section{Acknowledgement}

The author thanks to the Ministry of Agriculture and Forestry of Turkish Republic for allowing to use the facilities of Poultry Research Institute in Ankara.

\section{Conflict of Interest}

The authors declared that there is no conflict of interest.

\section{References}

1. Ahrabi O (2015): Heritabilities and genetic correlations for egg weight traits in Iranian fowl by multi trait and random regression models. Int J Adv Biol Biom Res, 3, $108-111$.

2. Anang A, Mielenz N, Schüler L (2000): Genetic and phenotypic parameters for monthly egg production in White Leghorn hens. J Anim Breed Genet, 117, 407-415.

3. Anonymous (2019): Hy-Line commercial breeder management guide.

https://www.hyline.com/userdocs/pages/BRN_PS_ENG.pdf. (1 May 2019).

4. Anonymous (2019): Hy-Line management guide .https://www.hyline.com/UserDocs/Pages/BRN_COM_EN G.pdf. (1 May 2019).

5. Anonymous (2019): Lohman commercial breeding management guide. https://www.hyline.com/userdocs/pages/BRN_PS_ENG.pdf. (1 May 2019).

6. Aulchenko YS, Ripke S, Isaacs A, et al. (2007): GenABEL: an $R$ package for genome-wide association analysis. Bioinformatics, 23, 1294-1296.

7. Besbes B, Ducrocq V, Foulley JL, et al. (1992): Estimation of genetic parameters of egg production traits of laying hens by restricted maximum likelihood applied to a multiple-trait reduced animal model. Genet Sel Evol, 24, 539-552.

8. Besbes B, Gibson JP (1999): Genetic variation of egg production traits in purebred and crossbred laying hens. Anim Sci, 68, 433-439.

9. Francesch A, Estany J, Alfonso L, et al. (1997): Genetic parameters for egg number, egg weight, and eggshell color in three Catalan poultry breeds. Poult Sci, 76, 1627-1631.

10. Goger H, Demirtas S, Yurtogullari S (2014): Developments in the performance of brown egg layer parental stocks for superior hybrid. Turk J Vet Anim Sci, 38, 546-551.

11. Hoffmann I (2005): Research and investment in poultry genetic resources-challenges and option for sustainable use. World Poultry Sci J, 61, 57-70.

12. Johansson K, Orberg J, Carlgren AB (1996): Selection for egg shell strength in laying hens using shell membrane characteristics. Br Poultry Sci, 37, 757-763.

13. Kamali MA, Ghorbani SH, Sharbabak MM, et al. (2007): Heritabilities and genetic correlations of economic traits in Iranian native fowl and estimated genetic trend and inbreeding coefficients. Br Poultry Sci, 48, 443-448.

14. Kumar R, Kalra S, Singh S (2013): Genetic and phenotypic parameters of economic traits in White Leghorn. Ind J Anim Res, 47, 132-136.

15. Kumari P B, Gupta BR, Prakash MG, et al. (2009): Genetic study on body weights of Japanese quails. Int $\mathbf{J}$ Poult Sci, 44, 301-307.

16. Lillpers K, Wilhelmson M (1993): Age-dependent changes in oviposition pattern and egg production traits in the domestic hen. Poult Sci, 72, 2005-2011. 
17. Lwelamira J, Kifaro G, Gwakisa P (2009): Genetic parameters for body weights, egg traits and antibody response against Newcastle Disease Virus (NDV) vaccine among two Tanzania chicken ecotypes. Trop Anim Health Prod, 41, 51-59.

18. Mizrak C, Boga A, Durmus I, et al. (2010): Various production characteristics of white layer breeders developed in the Poultry Research Institute. J Poult Res, 9, 5-10.

19. Narinc D, Aksoy T, Kaplan S (2016): Effects of multi-trait selection on phenotypic and genetic changes in Japanese quail (Coturnix coturnix japonica), J Poult Sci, 53, 103-110.

20. Narinc D, Karaman E, Aksoy T (2014): Effects of slaughter age and mass selection on slaughter and carcass characteristics in 2 lines of Japanese quail. Poult Sci, 93, 762-769.

21. Niknafs S, Nejati-Javaremi A, Mehrabani-Yeganeh $\mathbf{H}$, et al. (2012): Estimation of genetic parameters for body weight and egg production traits in Mazandaran native chicken. Trop Anim Health Prod, 44, 1437-1443.

22. Padhi MK, Chatterjee RN, Rajkumar U, et al. (2015): Genetic and phenotypic parameters estimates for body weight, conformation, production and reproduction traits of PD1 (Vanaraja male line) during different periods. Ind J of Anim Sci, 85, 883-888.

23. Peebles ED, Gardner CW, Brake J, et al. (2000): Albumen height and yolk and embryo compositions in broiler hatching eggs during incubation. Poult Sci, 79, 1373-1377.

24. Preisinger R, Savas T (1997): Vergleich zweier Methoden zur Schätzung der Varianzkomponenten für Leistungmerkmale bei Legehennen. Züchtungskunde, 69, 142-152.

25. Quinton M (2003): Use of mixed model methodology in poultry breeding: Assumptions, limitations and concerns of BLUP-based selection programmes. 203-235. In, Muir WM, Aggrey SE (Eds): Poultry Genetics, Breeding Biotechnology. CAB Int, Wallingford, Oxfordshire, UK.

26. Rayan GN, Galal A, Fathi MM, et al. (2010): Impact of layer breeder flock age and strain on mechanical and ultra structural properties of eggshell in chicken. Int J Poult Sci, 9, 139-147.
27. Roberts JR, Chousalkar K, Samiullah S (2013): Egg quality and age of laying hens: implications for product safety. Anim Prod Sci, 53, 1291-1297.

28. Samiullah S, Roberts JR (2013): The location of protoporphyrin in the eggshell of brown-shelled eggs. Poult Sci, 92, 2783-2788.

29. Savas TR, Preisinger R, Roehe E, et al. (1999): Effect of inbreeding on production traits and their genetic parameters in laying hens. Arch Geflügelkd, 63, 246-251.

30. Savegnago RP, Buzanskas ME, Nunes BN, et al. (2011): Heritabilities and genetic correlations for reproductive traits in an F2 reciprocal cross chicken population. Genet Mol Res, 10, 1337-1344.

31. Singh CB, Singh CV, Dev C (2011): Production performance of native fowl of Garhwal Himalayas reared under deep litter system. Ind J Poul Sci, 46, 119-120.

32. Szwaczkowski T (2003): Use of mixed model methodology in poultry breeding: Estimation of genetic parameters. 165201. In, Muir WM, Aggrey SE (Eds): Poultry Genetics Breeding and Biotechnology, $\mathrm{CAB}$ Int, Wallingford, Oxfordshire, UK.

33. Thiruvenkadan A, Panneerselvam S, Prabakaran $\mathbf{R}$ (2010): Layer breeding strategies: an overview. World Poultry Sci J, 66, 477-501.

34. Thiruvenkadan A, Prabakaran R (2017): Recent approaches in poultry breeding. Appro Poult Dairy \& Vet Sci, 2, APDV.000533, 2017. DOI: 10.31031/APDV.2017.02.000533

35. Veeramani P, Churchil R, Kutty KN (2012): Estimates of heritability and correlations of economic traits in two strains of White Leghorn. Int J Vet Sci, 1, 45-48.

36. Venturini GC, Grossi DA, Ramos SB, et al. (2012): Estimation of genetic parameters for partial egg production periods by means of random regression models. Genet Mol Res, 11, 1819-1829.

37. Wolc A, Arango J, Settar P, et al. (2011): Evaluation of egg production in layers using random regression models. Poult Sci, 90, 30-34.

38. Wolc A, Szwaczkowski T (2009): Estimation of genetic parameters for monthly egg production in laying hens based on random regression models. J Appl Genet, 50, 41-46.

39. Zhang LC, Ning ZH, Xu GY, et al. (2010): Heritability and genetic and phenotypic correlations of egg quality traits in Bovan-Egg duarf layers. Poult Sci, 84, 1209-1213. 